\title{
PERBANDINGAN FORMULA ENTERAL RENDAH LEMAK BERBASIS TEPUNG EDAMAME DENGAN FORMULA KOMERSIAL RENDAH LEMAK
}

\author{
Comparison of Edamame Flour Based Low Fat Enteral Formula with \\ Commercial Low Fat Formula \\ Siti Aliyah ${ }^{1 *}$, Suci Indah Setiawati ${ }^{2}$ \\ ${ }^{1}$ RSU Haji Surabaya \\ ${ }^{2}$ Progam Studi Gizi Klinik, Jurusan Kesehatan, Politeknik Negeri Jember \\ E-mail: sitialiyahrsuhaji@gmail.com
}

\begin{abstract}
ABSTRAK
Dislipidemia merupakan faktor utama terbentuknya aterosklerosis dan dapat mengakibatkan terjadinya penyakit sirkulasi darah. Edamame merupakan pangan fungsional yang mengandung asam lemak omega-3 dan komponen fitokimia yaitu isoflavon, sterol, dan saponin, serta kandungan serat pangan yang tinggi. Edamame terbukti mempunyai kemampuan dalam menurunkan kolesterol LDL. Penelitian ini bertujuan untuk menganalisis perbedaan formula enteral rendah lemak berbasis tepung edamame dengan formula komersial rendah lemak. Penelitian ini adalah penelitian deskriptif komparatif. Metode pengumpulan data dilakukan dengan perhitungan terhadap nilai zat gizi dan bioavailabilitas protein, serta pengujian mutu hedonik formula enteral rendah lemak substitusi tepung edamame. Hasil penelitian menunjukkan kandungan lemak formula modifikasi adalah $26,4 \%$ dari kebutuhan energi total dan nilai tersebut telah memenuhi syarat diet dislipidemia bahwa kandungan lemak harus $<30 \%$ dari kebutuhan energi total. Kandungan lemak dalam formula ini sebagian besar adalah lemak tidak jenuh yang berasal dari kedelai edamame yaitu asam lemak omega-3 dan minyak zaitun yaitu asam lemak omega-9. Nilai bioavailabilitas yaitu skor asam amino sebesar 32,18, mutu cerna teoritis sebesar 89,27, Net Protein Utilization sebesar 28,73, protein senilai telur sebesar 16,77 dan protein energi rasio sebesar 4,51. Hasil uji mutu hedonik menunjukkan bahwa warna formula enteral berbasis tepung edamame adalah cokelat muda, rasanya manis, berbau khas edamame, dan memiliki konsistensi cair. Berdasarkan perbandingan formula enteral komersial dengan formula enteral non komersial berbasis tepung edamame, dapat disimpulkan bahwa formula enteral berbasis tepung edamame dapat direkomendasikan sebagai formula enteral non komersial untuk pasien dislipidemia menggantikan formula komersial.
\end{abstract}

Kata kunci: dislipidemia, formula enteral rendah lemak, tepung edamame

\section{ABSTRACT}

Dyslipidemia leads to atherosclerosis which is a risk factor for cardiovascular diseases. Edamame contains omega-3 fatty acids and phytochemical components such as isoflavones, sterols and saponins, and also high in fiber content. Edamame has been proved to have ability to decrease LDL cholesterol level. This research aims to analyze the comparison of edamame flour based low fat enteral formula with commercial low fat formula. This was a descriptive comparatif research design. Data collection was done by doing calculations on nutrient content and bioavailability protein, also organoleptic quality of low fat enteral formula with edamame flour substitution. The result showed that fat content of modified formula was $26.4 \%$ of total energy requirement and the value had met dietary requirement for dyslipidemia diet which is not more than $<30 \%$ of total energy requirement. Type of fat in this formula largely contains unsaturated fats derived from omega-3 fatty acids of soy edamame and omega-9 fatty acids from olive oil. The value of protein bioavailability which was shown from Amino Acid Score was 32.18, Theoretical Digestibility was 89.27, Net Protein Utilization was 28.73, Protein Worth of Eggs was 16.77, and Protein Efficiency Ratio was 4.51. The result of hedonic quality test showed that the color of low fat enteral formula with edamame flour substitution was light brown, the taste was sweet, the smell was typical edamame aroma, and had liquid consistency. Based on the comparison of

Siti Aliyah, et al., MGI(2018) 1-11

DOI: $10.20473 /$ mgi.v13i1.1-11. 
commercial enteral formula with non-commercial enteral formula based on edamame flour, it can be concluded that edamame based flour enteral formula can be recommended as a non-commercial enteral formula for patients with dyslipidemia replacing commercial formula.

Keywords: dyslipidemia, formula enteral low fat, edamame flour

\section{PENDAHULUAN}

Dislipidemia adalah kelainan metabolisme lipid yang ditandai dengan peningkatan atau penurunan fraksi lipid dalam plasma. Kelainan fraksi lipid yang utama adalah kenaikan kadar kolesterol total, kolesterol LDL, dan trigliserida serta penurunan kadar kolesterol HDL. Peningkatan kadar kolesterol, terutama LDL, atau trigliserida darah perlu mendapat perhatian karena merupakan predisposisi terhadap terjadinya aterosklerosis atau Penyakit Jantung Koroner. Namun HDL mempunyai pengaruh sebaliknya. Peningkatan kadar HDL plasma menurunkan risiko terhadap Penyakit Jantung Koroner. Rendahnya kadar HDL dihubungkan dengan hipertrigliserida (Almatsier, 2010).

Data di Indonesia berdasarkan laporan Riskesdas Bidang Biomedis tahun 2007 menunjukkan bahwa prevalensi dislipidemia atas dasar konsentrasi kolesterol total $>200 \mathrm{mg} /$ dL adalah 39,8\% (PERKI, 2013). Pengobatan dislipidemia berdasarkan asumsi bahwa normalisasi nilai lipid darah mengurangi risiko terhadap aterogenesis dan penyakit kardiovaskuler. Kolesterol terutama disintesi di dalam hati dari hasil metabolisme karbohidrat, lemak, dan protein. Penyebab utama peningkatan kolesterol dalam darah adalah faktor keturunan dan asupan lemak tinggi. Asupan lemak total berhubungan dengan kegemukan, yang merupakan faktor risiko utama terserang aterosklerosis. Pengaruh lemak makanan pada penyakit jantung koroner berhubungan dengan pengaruh komponen asam lemak dan kolesterol terhadap kolesterol darah, terutama kolesterol LDL. Serat larut air, karbohidrat kompleks, dan diet vegetarian mempunyai pengaruh baik terhadap kadar lipid darah, sedangkan asam lemak jenuh, kolesterol dan kegemukan mempunyai pengaruh kurang baik terhadap kadar lipid darah yang berkaitan dengan risiko Penyakit Jantung Koroner. Pilar utama pengelolaan dislipidemia adalah upaya nonfarmakologis yang meliputi modifikasi diet, latihan jasmani, dan pengelolaan berat badan (Almatsier, 2010).

Trigliserida dalam tubuh berasal dari lemak makanan atau dari hasil perubahan unsur-unsur energi yang berlebihan di dalam tubuh. Trigliserida diangkut oleh Very Low Density Lipoprotein (VLDL) atau kilomikron ke jaringan tubuh sebagai sumber energi atau jaringan lemak untuk disimpan (Almatsier, 2010).

Tahap awal penatalaksanaan diet dislipidemia pada dasarnya adalah pembatasan jumlah lemak yaitu $<30 \%$ dari kebutuhan energi total (Almatsier, 2010). Pasien dengan kadar kolesterol LDL atau kolesterol total tinggi dianjurkan untuk mengurangi asupan lemak jenuh dan meningkatkan asupan lemak tidak jenuh rantai tunggal dan ganda, yaitu MUFA (Mono Unsaturated Fatty Acid) dan PUFA (Poly Unsaturated Fatty Acid). Asupan lemak jenuh untuk penderita dislipidemia dibatasi $<7 \%$ dari kebutuhan energi total. Sedangkan anjuran asupan lemak tak jenuh ganda dan tunggal yaitu $15-20 \%$ dari kebutuhan energi total, serta asupan kolesterol hanya diperbolehkan $<200-300$ mg/hari (Adam, 2006).

Penderita dislipidemia yang mengalami gangguan makan atau tidak mampu mengonsumsi zat gizi melalui oral secara total atau sebagian dapat berakibat pada terjadinya penurunan status gizi. Intervensi yang dianjurkan untuk mengatasi keadaan tersebut adalah melalui pemberian diet khusus. Diet khusus ini berupa formula enteral yang diberikan kepada pasien dislipidemia dengan gangguan atau penurunan fungsi makan lewat oral untuk menghindari terjadinya malnutrisi karena asupan zat gizi pasien yang tidak adekuat (Almatsier, 2010).

Formula enteral rendah lemak adalah salah satu formula enteral yang dapat diberikan kepada pasien dislipidemia dengan tujuan memberikan makanan tinggi kalori dan rendah lemak untuk memenuhi kebutuhan zat gizi pasien dislipidemia yang tidak dapat memenuhi kebutuhan zat gizinya 
melalui rute oral. Pemberian gizi penderita dislipidemia perlu diperhatikan, salah satunya dengan terapi enteral agar tidak terjadi overfeeding (Hartono, 2006).

Salah satu formula enteral komersial yang dapat diberikan kepada pasien dislipidemia adalah formula komersial rendah lemak yang memiliki kandungan energi $62,5 \mathrm{kkal}$ per $20 \mathrm{~g}$. Akan tetapi, harga formula enteral komersial cukup mahal sehingga dibutuhkan alternatif bahan makanan yang dapat digunakan sebagai bahan untuk membuat formula enteral tinggi kalori dan rendah lemak dengan berharga ekonomis (Anisa, 2013).

Pengembangan makanan formula enteral saat ini tidak hanya dapat dibuat dengan bahan dasar susu full cream dan susu skim, namun juga dapat disubstitusikan dengan menggunakan bahan lain tanpa mengurangi nilai energi dari formula standar Rumah Sakit. Mensubtitusikan suatu bahan yang mengandung lemak rendah merupakan salah satu cara untuk menanggulangi masalah dislipidemia. Salah satu bahan yang mungkin digunakan adalah tepung edamame, dimana bahan tersebut merupakan bahan makanan yang memiliki kandungan lemak yang rendah serta mengandung zat gizi yang dibutuhkan oleh penderita dislipidemia (Winarti, 2010).

Edamame merupakan pangan fungsional yang sangat potensial karena mengandung komponen bioaktif. Edamame mengandung asam lemak omega-3 EPA dan asam arakvidonat yang merupakan unsur utama sintesa senyawa prostaglandin yang berperan dalam kesehatan sistem peredaran darah dari proses ateroskierosis dan dapat menurunkan LDL dan meningkatkan HDL, serta mengandung komponen fitokimia yaitu isoflavon $(0.1-3.0 \%)$, sterol $(0.23-0.46 \%)$, dan saponin $(0.17-6.16 \%)$ yang dapat mereduksi risiko penyakit tidak menular seperti hipertensi, hiperlipidemia, penyakit jantung, dan stroke (Muaris, 2013; Winarti, 2010).

Senyawa polifenol terdiri dari beberapa subkelas, salah satunya yang terdapat dalam edamame yaitu isoflavon. Flavonoid berfungsi meningkatkan aktivitas vitamin $\mathrm{C}$ sebagai antioksidan dalam mencegah oksidasi kolesterol jahat (LDL) yang dapat mengakibatkan kerusakan dinding pembuluh arteri dan menghambat penggumpalan keping-keping darah. Komponen lain dalam kedelai yang dapat menurunkan kolesterol antara lain serat, saponin dan fitosterol. Serat pangan dapat menurunkan kolesterol darah dengan dua cara pertama adalah dengan mengikat kolesterol pada pangan, kedua adalah dengan mengikat kolesterol yang akan berasal dari penghancuran asam empedu. Akibatnya, untuk memproduksi asam empedu, diambil kolesterol yang berasal dari darah. Di dalam saluran pencernaan, serat larut akan mengikat asam empedu (produk akhir kolesterol) yang kemudian dikeluarkan bersama tinja. Serat larut air menurunkan kadar kolesterol darah hingga 5\% atau lebih. Saponin secara kimia mirip dengan kolesterol dan dapat memblokir penyerapan kolesterol dan meningkatkan sekresi kolesterol dari dalam tubuh. Fitosterol dapat menurunkan kolesterol dengan cara berkompetisi dengan kolesterol dalam proses penyerapan di usus halus (Muaris, 2013; Winarti, 2010).

Edamame memiliki kandungan protein lebih banyak daripada jenis pangan nabati lainnya. Protein edamame kaya asam amino glisin dan orginin yang mempunyai kecenderungan dapat menurunkan insulin darah yang diikuti dengan penurunan sintesa kolesterol. Jenis protein terbesar dalam kedelai adalah dua jenis globulin yang diberi nama 11S (glisinin) dan 7S (beta konglisinin), yaitu protein dominan pada biji kedelai (sekitar $80 \%$ ). Kedua jenis globulin tersebut, terutama $7 \mathrm{~S}$ telah terbukti dapat menstimulir tingginya afinitas reseptor kolesterol LDL dalam hati manusia yang akan menyebabkan penurunan kolesterol darah (Wisaniyasa et al., 2001).

Terdapat bukti dari penelitian pada hewan dan penelitian klinik yang menyatakan bahwa kacang kedelai (Glycine $\max$ (L.) Merr.) memberikan manfaat kesehatan, termasuk perbaikan profil lipid plasma yang diteliti oleh Chiechi et al. (2002). Selain itu, penelitian yang dilakukan oleh Nurcahyaningtyas (2012) membuktikan bahwa susu kacang kedelai dengan dosis $9 \mathrm{~g} / \mathrm{kg}$ berat badan dapat menurunkan kadar kolesterol total, trigliserida, dan kolesterol LDL Tikus putih jantan galur Sprague dawley. Penelitian lainnya yang dilakukan oleh Susanti (2014) juga menunjukkan hasil bahwa pemberian tepung kedelai edamame 
teroptimalisasi Bifidobacterium adolencentis dengan dosis 2,6 $\mathrm{g} / 200 \mathrm{~g}$ berat badan tikus/hari, mampu meningkatkan kadar HDL sebesar 32,8\% dan menurunkan kadar LDL tikus sebesar 63,7\%, yang setara dengan perlakuan obat simvastatin dengan dosis $0,18 \mathrm{mg} / 200 \mathrm{~g}$ berat badan tikus/ hari.

Berdasarkan kelebihan dari bahan pangan tepung kedelai edamame yang berpotensi sebagai bahan utama dalam pembuatan formula enteral untuk penderita penyakit dislipidemia, maka pada penelitian ini perlu dilakukan pengkajian untuk menilai apakah tepung kedelai edamame sebagai bahan modifikasi formula enteral diet dislipidemia dapat memenuhi persyaratan formula enteral diet dislipidemia yang telah ditetapkan.

Penelitian ini bertujuan untuk menganalisis mutu organoleptik, kandungan zat gizi, dan bioavailabilitas protein formula enteral rendah lemak berbasis tepung edamame, serta membandingkan antara formula enteral komersial dengan formula enteral rendah lemak berbasis tepung edamame dari segi nilai zat gizi, biaya, dan lama waktu pembuatan.

\section{METODE}

Metode penelitian yang digunakan yaitu metode deskriptif komparatif. Penelitian dilakukan selama 5 hari mulai tanggal 28 Februari 2017 hingga 4 Maret 2017. Variabel bebas dalam penelitian ini adalah tepung kedelai edamame, sedangkan variabel terikatnya yaitu mutu organoleptik, kandungan zat gizi, dan bioavailabilitas protein formula enteral substitusi tepung kedelai edamame.

Sumber data yang digunakan dalam penelitian ini adalah sumber data primer dan data sekunder. Sumber data primer diperoleh dari perhitungan kandungan zat gizi dan bioavailabilitas protein, perhitungan biaya dan lama waktu pembuatan, serta hasil uji organoleptik formula enteral rendah lemak berbasis tepung kedelai edamame. Data primer yang diperoleh kemudian dibandingkan dengan formula komersial. Adapun data sekunder yang digunakan adalah informasi yang diperoleh dari buku-buku atau dokumen tertulis seperti jurnal, skripsi, dan artikel yang berkaitan dengan penelitian yang dilakukan.

\section{Teknik Pengumpulan Data}

Pengolahan Formula Enteral Rendah Lemak Berbasis Tepung Edamame.

Bahan-bahan yang digunakan dalam penelitian ini yaitu tepung edamame komersial sebanyak $18 \mathrm{~g}$, susu skim bubuk $10 \mathrm{~g}$, susu full cream bubuk $5 \mathrm{~g}$, minyak zaitun $4 \mathrm{~g}$, tepung maizena $5 \mathrm{~g}$, gula pasir $20 \mathrm{~g}$, dan maltodextrin $5 \mathrm{~g}$. Sedangkan bahan untuk pembanding yaitu formula enteral rendah lemak komersial. Alat yang digunakan yaitu kompor, panci, gelas ukur, baskom, sendok, piring plastik, timbangan analitik. Langkah pembuatan formula enteral rendah lemak berbasis tepung kedelai edamame pada Gambar 1.

Pada penelitian ini, tepung kedelai edamame menggantikan produk enteral dalam pemberian diet sonde bagi pasien dislipidemia. Pada proses pengolahan, bahan baku susu full cream pada pembuatan formula enteral dikurangi jumlahnya, kemudian disubstitusikan dengan tepung edamame sebanyak $18 \mathrm{~g}$. Tujuan substitusi tersebut untuk mengurangi kandungan lemak jenuh di dalam formula enteral yang berasal susu full cream.

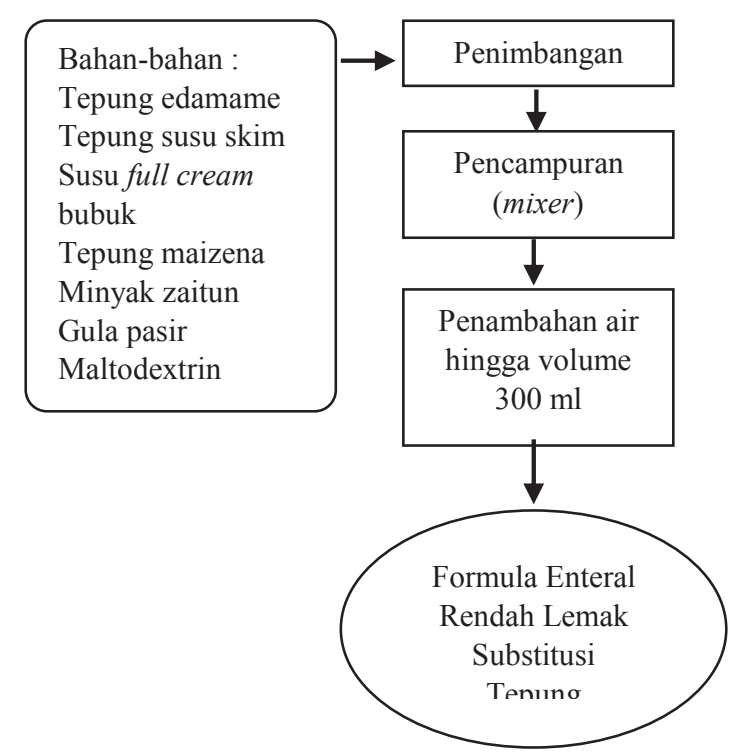

Gambar 1. Alur Pembuatan Formula Enteral Rendah Lemak Substitusi Tepung Edamame 
Kandungan zat gizi dan bioavailabilitas protein, perhitungan biaya dan lama waktu pembuatan formula enteral rendah lemak berbasis tepung kedelai edamame dilakukan pada tahap selanjutnya.

Uji organoleptik yang meliputi warna, rasa, aroma. kekentalan, formula enteral rendah lemak berbasis tepung edamame dilakukan oleh panelis semi terlatih sebanyak 15 orang yang berprofesi sebagai ahli gizi.

Analisis keunggulan dan kelemahan formula enteral rendah lemak berbasis tepung kedelai edamame dengan membandingkan nilai zat gizi, harga, dan lama waktu pembuatan antara formula enteral rendah lemak berbasis tepung kedelai edamame dengan formula komersial juga dilakukan.

\section{Metode Pengolahan Data}

Instrumen untuk analisis data yang digunakan yaitu menggunakan program SPSS 17.0. untuk menganalisis hasil uji organoleptik. Sedangkan analisis data yang digunakan untuk membandingkan hasil formula enteral berbasis tepung edamame dengan formula komersial adalah deskriptif komparatif, yaitu analisis yang membandingkan hasil formula enteral berbasis tepung edamame dengan formula komersial dengan kata-kata atau kalimat, kemudian dipisahkan menurut kategorinya. Kemudian dilakukan pengambilan kesimpulan dari data-data yang diperoleh setelah dianalisa untuk menjawab apa yang menjadi latar belakang penelitian.

\section{HASIL DAN PEMBAHASAN}

Formula enteral berbasis tepung edamame adalah bentuk modifikasi formula enteral yang memiliki kandungan lemak rendah, dimana bahan makanan yang disubstitusikan adalah tepung edamame. Formula ini diberikan kepada pasien dislipidemia yang memiliki gangguan menelan atau asupan zat gizi yang tidak adekuat.

\section{Nilai Zat Gizi}

Kandungan gizi formula enteral tepung edamame tidak dilakukan analisis proksimat (laboratorium), melainkan dianalisa menggunakan pendekatan Daftar Komposisi Bahan Makanan (DKBM). DKBM adalah daftar yang memuat susunan kandungan zat-zat gizi berbagai jenis bahan makanan atau makanan yang meliputi energi, karbohidrat, lemak, protein, vitamin dan kandungan mineral penting. DKBM dapat digunakan sebagai alat ukur untuk mengkonversi bahan makanan ke dalam nilai gizi karena data kandungan zat gizi yang dihimpun di dalam buku DKBM adalah hasil analisis yang dikerjakan oleh Pusat Penelitian dan Pengembangan Gizi. Dari beberapa hasil penelitian juga menunjukkan bahwa hasil uji proksimat suatu bahan pangan tidak berbeda nyata dengan nilai zat gizi bahan pangan yang tercantum di DKBM.

Setelah dilakukan perhitungan nilai zat gizi, diketahui nilai energi formula enteral substitusi tepung edamame per $300 \mathrm{ml}$ yaitu 297,484 kkal, sehingga didapatkan kepadatan kalori yaitu $1 \mathrm{kkal} / 1 \mathrm{ml}$ cairan. Nilai tersebut telah memenuhi persyaratan nilai kepadatan kalori formula enteral menurut AsDI (2005). Penelitian yang dilakukan oleh Muhlishoh (2013) juga menunjukkan kepadatan kalori yang berkisar antara 1,011,074 kalori/ml formula WHO 100. Kepadatan energi merupakan salah satu syarat suatu formula enteral, yaitu minimal sebesar $1 \mathrm{kalori} / \mathrm{ml}$ formula enteral, sehingga dengan volume yang kecil dapat memberikan asupan energi yang besar (Sobariah, et al., 2005).

Kandungan protein dari formula enteral substitusi tepung edamame yaitu 11,674 gam. Kandungan lemak yaitu 9,44 gam, lemak yang terkandung dalam formula enteral substitusi tepung edamame ini adalah $26,4 \%$ dari kebutuhan energi total dan nilai tersebut telah memenuhi syarat diet dislipidemia bahwa kandungan lemak harus $<30 \%$ dari kebutuhan energi total. Kandungan lemak dalam formula ini sebagian besar adalah lemak

Tabel 1. Perbandingan Nilai Zat Gizi Formula Enteral Komersial dan Non Komersial per 100 g

\begin{tabular}{ccc}
\hline Zat Gizi & $\begin{array}{c}\text { Formula } \\
\text { Komersial }\end{array}$ & $\begin{array}{c}\text { Formula Enteral } \\
\text { Tepung Edamame }\end{array}$ \\
\hline Energi (kkal) & 448 & 443 \\
Protein $(\mathrm{g})$ & 17 & 18 \\
Lemak $(\mathrm{g})$ & 14 & 13 \\
Karbohidrat $(\mathrm{g})$ & 65 & 61 \\
\hline
\end{tabular}


tidak jenuh yang berasal dari kedelai edamame yaitu asam lemak omega-3 dan minyak zaitun yaitu asam lemak omega-9.

Kandungan karbohidrat sebesar 40,58 gram, kandungan serat sebesar 4,246 g, dan kandungan kolesterol sebesar 4,642 mg. Tabel 1. menunjukkan perbandingan nilai zat gizi formula enteral komersial dengan formula enteral non komersial yaitu formula enteral substitusi tepung edamame.

Dari Tabel 1 diketahui perbandingan antara nilai zat gizi formula enteral komersial dengan formula enteral non komersial berbasis tepung edamame, dimana kandungan energi dan karbohidrat formula komersial lebih tinggi dibandingkan dengan kandungan energi formula enteral substitusi tepung edamame.

Akan tetapi, selisih nilainya tidak banyak sehingga masih bisa disejajarkan atau dikategorikan memenuhi kandungan energi dan karbohidrat untuk formula enteral rendah lemak. Sedangkan kandungan protein formula enteral substitusi tepung edamame lebih tinggi dan kandungan lemaknya lebih rendah dibandingkan dengan formula komersial.

Dalam setiap $100 \mathrm{~g}$ masing-masing formula enteral komersial dan non komersial, diketahui kandungan lemak formula enteral substitusi tepung edamame lebih rendah yaitu $13 \mathrm{~g} / 100 \mathrm{~g}$ formula dibandingkan formula komersial yang memiliki kandungan lemak $14 \mathrm{~g} / 100 \mathrm{~g}$ formula. Hal tersebut telah sesuai dengan tujuan dari pembuatan produk formula enteral non komersial dengan bahan baku tepung edamame, yaitu untuk menghasilkan produk formula enteral rendah lemak dan tinggi protein. Kandungan lemak yang lebih rendah dan kandungan protein yang lebih tinggi dibandingkan formula komersial menjadi kelebihan dari formula enteral edamame.

Berdasarkan kandungan zat gizinya, formula enteral substitusi tepung edamame dapat dijadikan alternatif formula enteral rendah lemak bagi pasien dislipidemia untuk menggantikan formula enteral komersial. Namun untuk mengetahui efektivitas dari formula enteral berbasis tepung edamame ini dalam menurunkan kadar kolesterol LDL perlu dilakukan penelitian uji coba In Vivo pada hewan coba. Penelitian yang dilakukan Purnamasari (2014) menunjukkan bahwa dosis $1,1 \mathrm{~g} / 200 \mathrm{~g} \mathrm{BB} /$ hari tepung edamame menurunkan kadar kolesterol tikus sebesar $0,93 \%$. Dosis $1,8 \mathrm{~g} / 200 \mathrm{~g} \mathrm{BB} /$ hari menurunkan kadar kolesterol $27 \%$ dan dosis 2,3 g/200g BB/hari menurunkan kadar kolesterol tikus sebesar $28 \%$.

\section{Bioavailabilitas Protein}

Terdapat 38 hasil studi yang menyimpulkan bahwa konsumsi protein kedelai (termasuk edamame) dapat menurunkan kolesterol total, kolesterol LDL dan trigliserida, tanpa menurunkan kolesterol HDL. Sinergi antara protein dan isoflavon diduga merupakan faktor utama dalam kemampuan kedelai menurunkan kolesterol. Dibandingkan dengan protein hewani, protein kedelai menurunkan penyerapan kolesterol dan asam empedu pada usus halus dengan menginduksi peningkatan ekskresi fekal asam empedu dan steroid. Hal ini mengakibatkan hati lebih banyak mengubah kolesterol dalam tubuh menjadi empedu, yang akibatnya dapat menurunkan kadar kolesterol dan meningkatkan aktivitas reseptor kolesterol LDL. Selanjutnya mengakibatkan peningkatan dalam laju penurunan kadar kolesterol (Samruan et al., 2012; dan Winarti, 2010).

Berdasarkan perhitungan secara teoritis, bioavailabilitas protein formula enteral substitusi tepung edamame diketahui Skor Asam Amino (SAA) sebesar 32,18, yang artinya bagian (proporsi) asam-asam amino esensial yang dimanfaatkan oleh tubuh dibandingkan dengan yang diserap adalah sebesar $32,18 \%$. Apabila dibandingkan dengan standar SAA (100), maka nilai SAA dari formula enteral berbasis tepung edamame tidak memenuhi standar, hal ini dikarenakan kedelai cenderung rendah kandungan asam amino belerang, yaitu metionin dan sistein. Akan tetapi, apabila dibandingkan dengan kacang-kacangan lain, jumlah asam amino metionin dan sistein pada kedelai masih lebih tinggi. Profil asam amino dalam protein kedelai cukup baik dibandingkan pola asam amino yang dibutuhkan tubuh. WHO telah menetapkan bahwa jika dikonsumsi sesuai anjuran konsumsi protein harian, protein kedelai mengandung jumlah semua asam amino esensial yang mencukupi kebutuhan tubuh manusia dan dapat disejajarkan dengan protein hewani. Dengan metode baru yang dikembangkan oleh WHO/FAO 
yaitu PDCAAS (Protein Digestibility Corrected Amino Acid Score), protein kedelai mempunyai skor asam amino yang sama dengan protein putih telur dan protein susu. Berdasarkan hasil studi dan pengukuran PDCAAS menunjukkan bahwa protein kedelai merupakan protein yang lengkap karena mempunyai tingkat "essentially equivalent" dalam mutu dibandingkan protein susu dan daging (Muaris, 2013; dan Winarti, 2010).

Meskipun rendah asam amino metionin dan sistein, namun kedelai edamame tinggi asam amino glisin dan arginin yang berpotensi menurunkan jumlah lemak jahat dalam tubuh. Hasil penelitian Nugahaningsih (2014) memberikan hasil bahwa tepung kedelai edamame teroptimalisasi Bifidobacterium adolencentis mampu menurunkan kadar trigliserida lebih cepat dibandingkan dengan obat. Hal ini disebabkan oleh asam amino glisin dan arginin yang ada pada tepung kedelai edamame mampu menjaga keseimbangan hormon insulin dimana hormon insulin bekerja secara langsung di jaringan adiposa. Insulin mempunyai peranan di dalam jaringan adiposa dalam mengontrol metabolisme lemak dengan menghambat lipolisis sehingga terjadi penurunan pengeluaran asam lemak dari jaringan adiposa ke dalam darah.

Mutu Cerna (MC) teoritis dari formula enteral berbasis tepung edamame adalah 89,27 , yang artinya formula ini dapat dicerna oleh tubuh secara maksimal. Mutu cerna ini menunjukkan bagian dari protein atau asam amino yang dapat diserap oleh tubuh dibandingkan yang dikonsumsi. Apabila dibandingkan dengan standar MC ( $\geq 85 \%$ kasein standar), maka nilai MC dari formula enteral berbasis tepung edamame memenuhi standar.

Net Protein Utilization (NPU) dari formula enteral berbasis tepung edamame adalah 28,73, yang artinya bagian protein atau asam amino yang dapat dimanfaatkan oleh tubuh dibandingkan protein atau asam amino yang dikonsumsi adalah sebesar 28,73\%. Nilai Protein Senilai Telur (PST) dari formula enteral berbasis tepung edamame adalah 16,77. Untuk menaksir Angka Kecukupan Protein (AKP) dalam bentuk protein kasar, diperlukan data dasar berupa Protein Senilai Telur (PST). PST ini berfungsi sebagai faktor koreksi mutu yang diperoleh dari nilai NPU. Protein Eficiency Ratio (PER) dari formula enteral berbasis tepung edamame adalah 4,51, yang artinya perbandingan energi dari Protein Senilai Telur (PST) terhadap total energi yang dikonsumsi dalam sehari adalah 4,51\%. PER ini menjadi ukuran mutu gizi konsumsi pangan karena protein dalam tubuh mempunyai fungsi utama sebagai pembangunan dan sumber energi. Dalam tubuh diperlukan adanya suatu keseimbangan tertentu antara kecukupan energi dan kecukupan protein. Nilai PER yang baik adalah dimana nilai konsumsi PST sama atau mendekati kecukupan PST pada saat kecukupan energi terpenuhi.

\section{Harga dan Lama Waktu Pembuatan}

Berikut ini adalah perbandingan harga dan lama waktu pembuatan formula enteral komersial dengan formula enteral non komersial yaitu formula enteral substitusi tepung edamame. Perbandingan disajikan pada Tabel 2.

Tabel 2. Biaya Pembuatan Formula Enteral Substitusi Tepung Edamame per Takaran Saji (67 g)

\begin{tabular}{lccc}
\hline \multicolumn{1}{c}{ Bahan Makanan } & Berat (g) & $\begin{array}{c}\text { Harga/kg } \\
\text { (Rp.) }\end{array}$ & $\begin{array}{c}\text { Harga } \\
\text { (Rp.) }\end{array}$ \\
\hline Tepung edamame & 18 & 40000 & 720 \\
Susu skim bubuk & 10 & 49000 & 490 \\
Susu full cream bubuk & 5 & 70000 & 35 \\
Tepung maizena & 5 & 16000 & 80 \\
Minyak zaitun & 4 & 98000 & 392 \\
Gula pasir & 25 & 16000 & 400 \\
Maltodextrin & 5 & 60000 & 300 \\
Total & 67 & & 2500 \\
\hline
\end{tabular}

Tabel 3. Perbandingan Harga Formula Enteral Komersial dan Formula Enteral Non Komersial per Takaran Saji

\begin{tabular}{lc}
\hline \multicolumn{1}{c}{ Jenis Formula Enteral } & Harga \\
\hline $\begin{array}{l}\text { Formula Komersial }(54 \mathrm{~g}) \\
\text { Formula enteral substitusi tepung } \\
\text { edamame }(67 \mathrm{~g})\end{array}$ & Rp. 13.000,- \\
\hline
\end{tabular}

Formula enteral berbasis tepung edamame selain memiliki kelebihan dari segi nilai gizi protein, juga memiliki harga yang ekonomis dibandingkan dengan harga formula enteral komersial. Harga formula enteral substitusi edamame yaitu Rp. 2500 per takaran saji, lebih murah dibandingkan formula komersial yang berharga Rp. 13.000 per takaran saji. Dengan 
Tabel 4. Perbandingan Waktu Pengolahan Formula Enteral Komersial dan Formula Enteral Non Komersial

\begin{tabular}{lcc}
\hline \multirow{1}{*}{ Proses } & \multicolumn{2}{c}{ Waktu } \\
\cline { 2 - 3 } & $\begin{array}{c}\text { Formula } \\
\text { Komersial }\end{array}$ & $\begin{array}{c}\text { Formula Enteral } \\
\text { Substitusi Tepung } \\
\text { Edamame }\end{array}$ \\
\hline $\begin{array}{l}\text { Perebusan air } \\
\text { Penimbangan bahan }\end{array}$ & 5 menit & 5 menit \\
$\begin{array}{l}\text { Persiapan susu } \\
\text { Pencampuran bahan } \\
\text { Penyajian dengan air } \\
\text { hangat }\end{array}$ & 2 menit & 5 menit \\
\hline Total & - & - \\
\hline
\end{tabular}

nilai zat gizi yang setara dan harga yang lebih ekonomis, maka formula enteral substitusi tepung edamame dapat direkomendasikan untuk menggantikan formula enteral komersial bagi pasien dislipidemia.

Pada Tabel 4 diketahui perbandingan waktu pengolahan antara pengolahan formula enteral komersial dengan waktu pengolahan formula enteral non komersial adalah 1: 2. Pengolahan formula enteral substitusi tepung edamame membutuhkan waktu yang lebih lama yaitu 15 menit. Hal tersebut dikarenakan masih ada proses penimbangan bahan dan pencampuran bahan. Sehingga waktu untuk pengolahan lebih lama dibandingkan dengan pengolahan formula komersial yang hanya tinggal menakar formula bubuk dan menambahkan air. Selisih waktu keduanya hanya sebanyak 5 menit.

\section{Uji Mutu Hedonik}

Uji mutu hedonik dilakukan dengan menggunakan hedonic scale scoring. Parameter penilaian terdiri dari warna, rasa, aroma dan kekentalan.

Skala penilaian warna dinyatakan dalam 5 tingkat:

Putih $\quad: 1$

Putih Kekuningan $\quad: 2$

Putih Kecokelatan : 3

Cokelat Muda $\quad: 4$

Cokelat Tua $: 5$

Skala penilaian rasa dinyatakan dalam 5 tingkat:

Sangat hambar $\quad: 1$

Hambar $\quad: 2$
Agak Hambar $\quad: 3$

Manis $\quad: 4$

Sangat manis $\quad: 5$

Skala penilaian aroma dinyatakan dalam 5 tingkat:

Aroma susu kuat $\quad: 1$

Sedikit berbau susu $\quad: 2$

Sedikit berbau khas edamame : 3

Berbau khas edamame $\quad: 4$

Segar, khas edamame $\quad: 5$

Skala penilaian kekentalan dinyatakan dalam 5 tingkat:

Sangat kental $: 1$

Kental $: 2$

Agak kental : 3

Cair $\quad: 4$

Sangat cair $\quad: 5$

\section{Warna}

Nilai yang sering muncul dari uji mutu hedonik warna formula enteral berbasis tepung

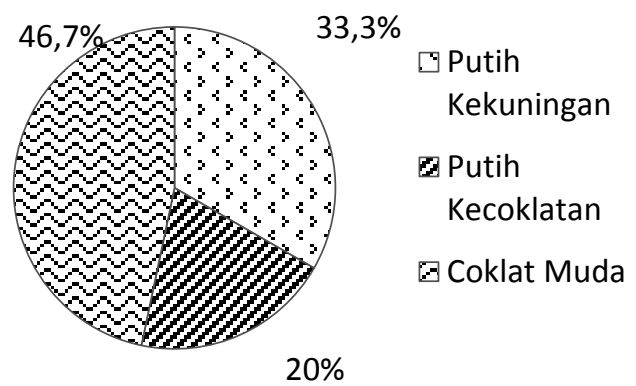

Gambar 2. Persentase Uji Mutu Hedonik Kategori Warna

edamame yaitu 4 , artinya formula enteral subtitusi tepung edamame berwarna cokelat muda.

Hasil uji mutu hedonik terhadap kategori warna dari formula enteral berbasis tepung edamame didapatkan hasil bahwa dari 15 panelis sebanyak 33,3\% (5 orang) menyatakan warna formula enteral berbasis tepung edamame yaitu putih kekuningan, 20\% (3 orang) menyatakan warna formula enteral berbasis tepung edamame yaitu putih kecokelatan, dan $46,7 \%$ ( 7 orang) menyatakan warna formula enteral berbasis tepung edamame yaitu cokelat muda. 


\section{Rasa}

Nilai yang sering muncul dari uji mutu hedonik rasa formula enteral berbasis tepung edamame yaitu 4, yang artinya formula enteral subtitusi tepung edamame memiliki rasa manis.

Hasil uji mutu hedonik terhadap kategori rasa dari formula enteral berbasis tepung edamame

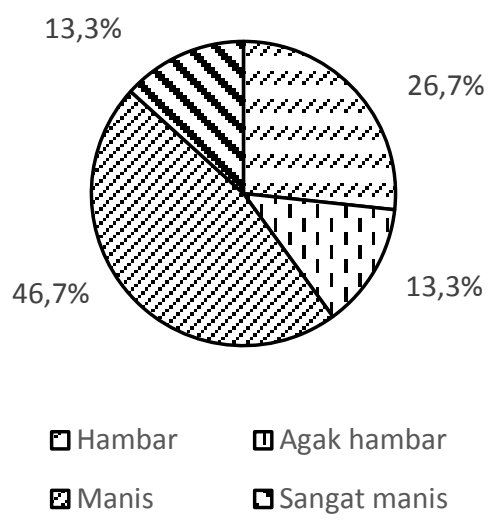

Gambar 3. Persentase Uji Mutu Hedonik Kategori Rasa

didapatkan hasil bahwa dari 15 panelis sebanyak $26,7 \%$ (4 orang) menyatakan rasa formula enteral berbasis tepung edamame yaitu hambar, 13,3\% (2 orang) menyatakan rasa formula enteral berbasis tepung edamame yaitu agak hambar, 46,7\% (7 orang) menyatakan rasa formula enteral berbasis tepung edamame yaitu manis, dan $13,3 \%$ ( 2 orang) menyatakan rasa formula enteral berbasis tepung edamame yaitu sangat manis.

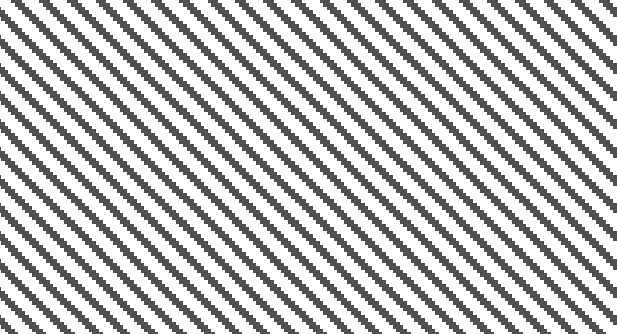

Gambar 4. Persentase Uji Mutu Hedonik Kategori Aroma

\section{Aroma}

Nilai yang sering muncul dari uji mutu hedonik aroma formula enteral berbasis tepung edamame yaitu 3 , artinya formula enteral berbasis tepung edamame memiliki aroma sedikit berbau khas edamame.

Hasil uji mutu hedonik terhadap kategori aroma dari formula enteral berbasis tepung edamame didapatkan hasil bahwa dari 15 panelis sebanyak 53,3\% (8 orang) menyatakan aroma formula enteral berbasis tepung edamame yaitu sedikit berbau khas edamame, dan $46,7 \%$ ( 7 orang) menyatakan aroma formula enteral berbasis tepung edamame yaitu berbau khas edamame.

\section{Kekentalan}

Nilai yang sering muncul dari uji mutu hedonik kekentalan formula enteral berbasis tepung edamame yaitu 4, artinya formula enteral berbasis tepung edamame memiliki tingkat konsistensi yang cair.

Hasil uji mutu hedonik terhadap kategori warna dari formula enteral berbasis tepung edamame didapatkan hasil bahwa dari 15 panelis sebanyak $6,7 \%$ (1 orang) menyatakan tingkat konsistensi formula enteral berbasis tepung edamame yaitu sangat kental, 20\% (3 orang) menyatakan tingkat konsistensi formula enteral berbasis tepung edamame yaitu kental, $6,7 \%$ (1 orang) menyatakan tingkat konsistensi formula enteral berbasis tepung edamame yaitu agak kental, dan $66,7 \%$ (10 orang) menyatakan tingkat konsistensi formula enteral berbasis tepung edamame yaitu cair.

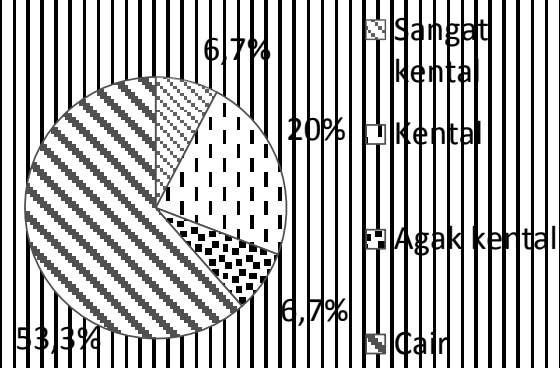

Gambar 5. Persentase Uji Mutu Hedonik Kategori Kekentalan 
Faktor penyebab panelis kurang menyukai aroma formula enteral substitusi tepung edamame adalah karena aroma formula yang langu yang berasal dari kedelai edamame, sedangkan alasan mengapa panelis kurang menyukai rasa formula enteral substitusi tepung edamame adalah karena rasa edamame yang terlalu kuat. Penelitian yang dilakukan oleh Muhlishoh (2013) memberikan hasil uji organoleptik bahwa rata-rata panelis kurang menyukai aroma dan rasa dari formula enteral substitusi tepung edamame. Penelitian lainnya yang dilakukan oleh Pudjirahayu (2008) juga memberikan hasil uji organoleptik yang ratarata kurang disukai oleh panelis dari segi rasa, aroma, dan warna. Solusi yang dapat diberikan adalah dengan menambah flavour makanan (bahan tambahan pangan) untuk memperbaiki aroma dan cita rasa formula dengan batas penggunaan yang aman.

\section{KESIMPULAN DAN SARAN}

\section{Kesimpulan}

Hasil penelitian menunjukkan bahwa kandungan zat gizi formula enteral substitusi tepung edamame adalah energi $443 \mathrm{kkal}$, protein 18 gram, lemak 13 gram, dan karbohidrat 61 gram. Kandungan lemak formula enteral substitusi tepung edamame adalah $26,4 \%$ dari kebutuhan energi total dan nilai tersebut telah memenuhi syarat diet dislipidemia yaitu kandungan lemak $<30 \%$ dari kebutuhan energi total, dengan kandungan lemak dalam formula ini sebagian besar adalah lemak tidak jenuh yang berasal dari kedelai edamame yaitu asam lemak omega-3 dan minyak zaitun yaitu asam lemak omega-9.

Berdasarkan perbandingan nilai zat gizi dan biaya formula enteral komersial dengan formula enteral non komersial berbasis tepung edamame, diketahui kandungan zat gizi formula enteral berbasis tepung edamame setara dengan kandungan zat gizi formula komersial dan harganya lebih ekonomis, sehingga formula substitusi tepung edamame dapat direkomendasikan sebagai formula enteral non komersial untuk pasien dislipidemia menggantikan formula komersial. Namun, untuk lebih memperkuat manfaatnya dapat dilakukan analisis zat gizi secara proksimat untuk memperoleh hasil yang lebih akurat dan dilakukan penelitian uji coba In Vivo.

\section{Saran}

Analisis zat gizi secara proksimat (laboratorium). Perlu dilakukan untuk memperoleh hasil yang lebih akurat. Penelitian uji coba In Vivo juga dapat dikembangkan untuk mengetahui manfaat formula enteral rendah lemak substitusi tepung edamame pada hewan coba.

\section{DAFTAR PUSTAKA}

Adam, John M.F. Dislipidemia. Dalam: Sudoyo, Aru W., Setiyohadi, Bambang., Alwi, Idrus., K, Marcellus S., dan Setiati, Siti (Ed.). (2006). Buku ajar ilmu penyakit dalam (Jilid III, Ed. IV). Jakarta: Pusat Penerbitan Ilmu Penyakit Dalam Fakultas Kedokteran Universitas Indonesia.

Almatsier, S. (2010). Penuntun diet edisi baru. Jakarta: PT. Gramedia Pustaka Utama.

Anisa, N. (2013). Pengembangan formula enteral untuk penyakit hepatitis $b$ berbahan baku ekonomis (Skripsi yang tidak dipublikasikan) Politeknik Negeri Jember, Jember.

AsDI. (2005). Panduan pemberian makanan enteral. Jakarta: CV Jaya Pratama.

Chiechi, L. M., Secreto, G., Vimercati, A., Geco, P., Venturelli, E., Pansini, F., Fanelli, M., Loizzi, P., \& Selvaggi, L. (2002). The effect of soy rich diet on serum lipids: the menfis randomized trial. Maturitas (41), 97-104. Diakses dari http://www.maturitas.org/article/ S0378-5122(01)00259-6/references

Hartono, A. (2006). Terapi gizi \& diet rumah sakit edisi 2. Jakarta: Penerbit Buku Kedokteran.

Muaris, H.J. (2013). Khasiat edamame untuk kestabilan kesehatan. Jakarta: PT. Gamedia Pustaka Utama.

Muhlishoh, A. (2012). Studi tentang substitusi tepung edamame pada pembuatan formula WHO 100 (Skripsi tidak dipublikasikan) Politeknik Negeri Jember, Jember

Nugahaningsih, S. (2014). Pengaruh Pemberian Tepung Kedelai Edamame Teroptimalisasi Bifidobacterium Adolencentis terhadap Kadar Trigliserida Tikus Hiperkolesterolemia (Skripsi yang tidak dipublikasikan) Politeknik Negeri Jember, Jember.

Nurcahyaningtyas, H.R. (2012). Efek antihiperlipidemia susu kacang kedelai 
(glycine max (l.) merr.) pada tikus putih jantan yang diberi diit tinggi kolesterol dan lemak (Skripsi yang tidak dipublikasikan) Universitas Indonesia, Jakarta

Pudjirahayu, A., E. Sulistyowati, A.H Santoso (2008). Studi pengembangan tepung tempe sebagai bahan substitusi pada formula enteral rumah sakit (hospital made). Jurnal Kesehatan, $6 ; 120$.

Purnamasari, I. (2014). Pengaruh tepung kecambah kedelai (glycine max (l.) merriil) terhadap penurunan kadar kolesterol total tikus jantan galur wistar hiperkolesterolemia. (Skripsi yang tidak dipublikasikan) Politeknik Negeri Jember, Jember.

Sobariah, E. \& Anita, M. (2005). Panduan pemberian makanan enteral. Jakarta: Asosiasi Dietisien Indonesia.
Samruan, W.R. Oonsivilai, \& A. Oonsivilai. (2012). Soybean and fermented soybean extract antioxidant activity. International Journal of Biological, Biomolecular, Agricultural, Food and Biotechnological Engineering, 6(12),1134$37 \mathrm{http}: / /$ www.waset.org/publications/13758.

Susanti, M. (2014). Pengaruh pemberian tepung kedelai edamame teroptimalisasi bifidobacterium adolencentis terhadap kadar $H D L$ dan LDL tikus hiperkolesterolemia (Skripsi yang tidak dipublikasikan) Politeknik Negeri Jember, Jember.

Winarti, S. (2010). Makanan fungsional. Yogyakarta: Graha Ilmu.

Wisaniyasa, N.W., Marsono \& Noor. (2001). Pengaruh diet protein kedelai terhadap profil lipida tikus diabetik induksi alloxan. Prosiding PATPI22(1), 58-63. 